\title{
Synthesis
}

\section{Education and Resilience: Social and Situated Learning among University and Secondary Students}

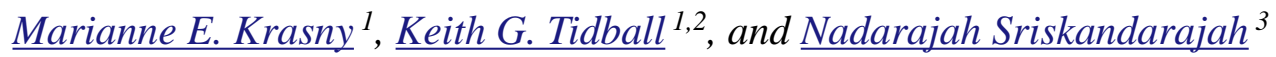

\begin{abstract}
Similar to research on social learning among adult participants in natural resources management, current research in the field of education claims that learning is situated in real-world practice, and occurs through recursive interactions between individual learners and their social and biophysical environment. In this article, we present an overview of the social and situated learning literatures from the fields of natural resources and education, and suggest ways in which educational programs for secondary and university students might be embedded in and contribute to efforts to enhance resilience of socialecological systems at the local scale. We also describe three initiatives in which learning is situated in adaptive co-management and civic ecology practices: a university graduate experiential learning course in Sweden, a pre-college environmental education program in the USA, and a university undergraduate service-learning class in the USA. Through integrating the social learning and adaptive management literature with the literature focusing on youth learning situated in authentic practice, we hope to: (1) suggest commonalities among systems views of learning and social-ecological systems perspectives on resilience, and (2) expand our thinking about educational practice from being a means to convey content matter to becoming a critical component of social-ecological systems and resilience.
\end{abstract}

Key Words: education; learning; natural resources management; resilience; situated learning; social learning

\section{INTRODUCTION}

Research about social and adaptive learning features prominently within the natural resources management and social-ecological systems resilience literatures, and focuses primarily on learning among groups of adult stakeholders involved in decision making related to watershed, wildlife, fisheries, and other resources (Gunderson 2001, Schusler et al. 2003, Berkes 2004, Olsson et al. 2004, Gunderson et al. 2006, Berkes et al. 2007, Blackmore et al. 2007a, Pahl-Wostl et al. 2007, Armitage et al. 2008, PahlWostl et al. 2008, Plummer and FitzGibbon 2008, Marschke and Sinclair 2009). In contrast, scant attention has been paid to the role of education of younger stakeholders in the adaptive comanagement and resilience literature, perhaps because our perception of education suggests a topdown transfer of information for predetermined outcomes, which in many ways is antithetical to systems notions of unpredictability, emergence, and interactions. However, similar to the way in which resilience scholars have questioned expert-driven management approaches (Folke 2006), environmental and science education scholars and practitioners increasingly are questioning content-driven, topdown, deterministic educational approaches for at least four reasons: these approaches may be ineffective in developing desired critical thinking and other skills (National Research Council (NRC) 1996); they do not take into account the variety of learning styles and diverse knowledge of nonwestern, female, and other students (Moll et al. 1992); they may inculcate students with behaviors designed to meet instrumental goals of the educators rather than focus on students realizing their own goals and potential (Wals et al. 2008); and they may reinforce predominant power structures (Bowers 2002).

As an alternative to content- and teacher-driven approaches, environmental and science educators have called for more participatory educational practices, including action-competence and similar 
approaches designed to build capacity among young people to make their own informed decisions about the environment (Jensen and Schnack 1997, Schusler et al. 2009) and inquiry learning, in which students conduct investigations focused on answering authentic scientific questions (NRC 1996). In these and similar participatory approaches, the outcomes relative to decisions that students make or results of their investigations are not prescribed in advance, but rather emerge from the interactions of the participants with their social and biophysical environment (Illeris 2007). In this sense, participatory education practices share many of the attributes that Masten and Obradovic (2008) cite as being common to resilience frameworks applied to both humans and social-ecological systems, including an emphasis on individual or ecosystem resilience and learning emerging from dynamic interactions and change; direction as probabilistic rather than deterministic because of the inherently dynamic nature of living, open systems, and the sheer number of interactions involved; recognition of multiple pathways that an individual or system may follow; reliance on flexibility and adaptive capacity for change rather than stability or equilibrium with return to the same steady state; and recognition of the role of human judgment in defining desirable or undesirable regimes or outcomes. Just as a systems resilience perspective shifts the focus from controlling change in systems assumed to be stable to managing the capacity of social-ecological systems to cope with, adapt to, and shape change (Folke 2006), participatory approaches to education seek not so much to control the direction of student learning but rather to create situations where, through ongoing interactions with the social and ecological elements of the larger system, students develop the capacity to play a meaningful role in shaping their own future and that of their larger community.

In this paper, we add to the existing natural resources literature on interdisciplinary and hands-on learning (e.g., Benbasat and Gass 2001, Galindo-Leal 2001) by examining university and $\mathrm{K}-12$ education programs through the lenses of social and situated learning theory and the resilience framework. These theories of learning emphasize interactions among the learner and the social and physical environment in which learning takes place and shed light on how education at the $\mathrm{K}-12$ and university level might foster social-ecological resilience at local and watershed scales. Throughout this paper, although recognizing various uses of the term resilience in the engineering and psychology literatures, we use resilience to describe the capacity of a socialecological system to buffer perturbances and to renew and reorganize in response to change, resulting in a more desirable system (Gunderson and Holling 2002, Folke 2006). The capacity to renew and reorganize depends in part on the ability to incorporate diverse forms of knowledge into management decisions and to learn adaptively (Folke et al. 2002, Berkes 2004). Importantly, for the purposes of this paper, we use the word education to refer to a program of inquiry, reflection, stewardship, and action learning activities embedded in real-life adaptive co-management or civic ecology practices that foster natural and social capital, and thus contribute to social-ecological system resilience. An education program embedded in such practices may also serve as a source of resilience by enhancing human capital and reinforcing the actual management or civic ecology practice.

Thus, the goal of this paper is to begin to address the gap in the literature bridging education at the university and secondary level with resilience thinking. Below, we present a brief overview of the literature on social learning within natural resources management. We next present a discussion of situated learning theories, which describe learning as moving from an inexperienced to skilled participant in authentic social and environmental practices, generally outside of the classroom (Rogoff and Lave 1984, Lave and Wenger 1991, Roth and Lee 2004, Boyer and Roth 2006). Although the focus of these theories is on individual learning as a result of recursive interactions with the social, biological, and physical aspects of the environment (Illeris 2007, Niewolny and Wilson 2009), they share much in common with social learning theories discussed in the adaptive management literatures (Blackmore et al. 2007a, Pahl-Wostl at al. 2007, 2008) and also offer insights into how educational programs might contribute to social-ecological system resilience. Three examples of educational programs in which learning is situated in adaptive co-management and civic ecology practices follow. The first example, an experiential graduate course at the Swedish University of Agricultural Sciences, aims to prepare facilitators of stakeholder engagement and social learning in adaptive co-management of a watershed involving multiple stakeholders with conflicting interests. The other two examples describe learning situated within civic ecology practice, which refers 
to the stewardship actions of community members who face negative impacts when a patch of habitat has fallen into less than optimal status as a result of neglect, abandonment, or lack of initiative, who recognize the potential of the patch of land for contributing to the social and environmental wellbeing of their community, and who take it upon themselves to restore the patch so that it provides social, cultural, and ecological services (Krasny and Tidball 2009). The two examples of learning situated within civic ecology practice include an environmental educational project that engages youth from after-school and summer programs in urban community gardening in the USA, and an undergraduate service-learning course that includes experiences situated in multiple civic ecology practices in the USA, including urban community forestry, wildlife restoration, and community gardening. After having examined the three example programs, we close by proposing an ecology of environmental education (Tidball and Krasny 2009) that highlights the potential interactions among educational programs and other components of social-ecological systems.

We recognize that the three examples included in this paper are descriptions from the perspective of the instructors or program leaders, rather than indepth case studies. Further, we recognize that in the absence of rigorous evaluations of these educational programs, we are unable to make definitive claims about their contributions to building the capacity to renew or reorganize in the face of ongoing change or disturbance. Thus, by integrating notions from social learning in the natural resources management literature with situated learning in the science and environmental education literatures and by presenting the educational examples, we are at an exploratory stage in uncovering relationships among education, learning, management, and resilience. Rather than presenting results, our intent is to begin a conversation about how education at the secondary and university levels may be integrated into ongoing scholarship and management practice designed to understand and to foster resilience.

\section{EDUCATION ABOUT, FOR, AND AS PART OF RESILIENT SOCIAL-ECOLOGICAL SYSTEMS}

In building an understanding of education and resilience, Fien's (1993) and Sterling's (2003) distinctions between education about and education for the environment or sustainability may prove useful. Whereas education about the environment is content driven, education for the environment trains students to think critically about environmental issues and to take action to address such issues (Fien 1993). Similarly, we suggest that education not only may be about resilience as a concept, but also may guide students in fostering resilience within the watershed, neighborhood, or other social-ecological system in which they work and live. The critical thinking and action skills inherent to education for the environment, as well as skills that address resilience attributes such as the ability to incorporate multiple forms of knowledge and perspectives in management decision making, would be important in education that is designed to foster resilience. Several researchers have begun to investigate the direct impact of education for the environment on environmental quality (Cline et al. 2002, Duffin et al. 2007, Short 2007). Similarly, researchers examining education for socialecological systems resilience might examine outcomes related to ecosystem services, social capital, social learning, and other attributes of resilient systems (Walker et al. 2002, Plummer and FitzGibbon 2008).

Building on Masten and Obradovic's (2008) call for examining embedded system processes in resilience scholarship, we also might consider the interactions of the educational programs themselves with resource management practices and other system elements. For example, environmental educational programs may become part of feedback loops focused on resource management, and may be viewed as drivers of processes and components within larger social-ecological systems. We use the term ecology of environmental education to describe scholarship that examines the interactions of educational programs with other components of a social-ecological system (Tidball and Krasny 2009).

\section{SOCIAL LEARNING WITHIN NATURAL RESOURCES MANAGEMENT CONTEXTS}

Schusler et al. (2003) defined social learning as learning that occurs when people engage one another, sharing diverse perspectives and experiences to develop a common framework of understanding and basis for joint action. These authors investigated social learning processes and 
outcomes during a 2-day search conference, through which diverse, local stakeholders engaged in collaborative planning focusing on wildlife management in the Great Lakes region of the USA. Participants in the conference learned about facts related to the resource, concerns of other stakeholders, and possible management actions, but were unlikely after a single search conference to take action to address the resource management issues. Drawing from case studies of management in 10 European river basins, Pahl-Wostl et al. (2007) presented a conceptual framework for social learning that occurred when stakeholder groups interacted on an ongoing basis; this framework emphasized the context for learning, the actual learning process itself, and the outcomes, each of which integrated both technical and social aspects of the management issue. Mostert et al. (2007) examined participatory processes in the same 10 case studies, and found that processes for stakeholder involvement varied across cases, and included stakeholder forums, newsletters, and participation in steering committees, working groups, and informational meetings. Similarly, Plummer and FitzGibbon (2008) used a case-study approach to examine social learning among three watershed stakeholder groups that participated in meetings to discuss management options, one of which also took actions, such as hosting community events to generate interest in the resource and completing a watershed plan.

In the above examples of social learning as part of wildlife and watershed co-management, the primary means of stakeholder involvement was through planning and informational meetings. Tidball and Krasny (2007) described examples of social learning that occurs within the context of hands-on stewardship or civic ecology practices, including community gardening, community forestry, watershed restoration, and similar community-based or "self-organized" management practices that integrate environmental, social, and civic values. Whereas the focus of civic ecology practices is engagement in local resource stewardship to enhance resilience at the individual and local social-ecological system levels, individuals participating in such activities may also become involved in planning and advocacy to protect the resources that they are stewarding, such as occurs in social learning within the natural resources management contexts cited above.

Other means in which volunteers and stakeholders might engage in social learning include monitoring programs focusing on aquatic resources organized by watershed networks, and citizen science projects that involve volunteers across a broad geographic region in collecting population data on birds, insects, and other wildlife (Krasny and Bonney 2005). Going a step further, the Canadian Community Monitoring Network (CCMN 2008) engaged citizens in both planning and hands-on monitoring of the physical resource. Through a fourstage process, CCMN participants set management priorities, assessed and enhanced their own capacity, monitored the physical resource, and shared information to inform local decision making. Similarly, community forestry projects described by Fernandez-Gimenez et al. (2008) integrated monitoring with social learning (Silverman 2008). The ability to use monitoring to respond to environmental change can tighten feedback loops and thus contribute to adaptability (Walker et al. 2006).

A number of authors have demonstrated the depth of learning that occurs through interaction with other learners (e.g., Hake 2002) and through engagement in different types of management experiences. Plummer and FitzGibbon (2008) found that the extent of social learning, including developing a systems orientation, exchanging perspectives, integrating different forms of knowledge, and reflection leading to a questioning of assumptions ( multiple- or higher-loop learning; Marquardt Arévalo et al. 2009), depended largely on the degree of stakeholder participation. Gunderson et al. (2006) claimed that incremental learning occurs in situations when models for resource management are assumed to be correct and learning entails collecting data or information to update those models; this is the type of learning one might expect in projects in which volunteers collect monitoring data (e.g., citizen science projects). In contrast, when stakeholders are involved in management decision making, several types of learning are possible, including episodic learning, which entails questioning underlying models, and transformational learning, which involves reframing the problem domain (Gunderson et al. 2006).

\section{SITUATED THEORIES OF LEARNING}

Parallel to social learning that occurs within the context of watershed management planning described above (Mostert et al. 2007, Pahl-Wostl et al. 2007, 2008, Plummer and FitzGibbon 2008), an action competence approach to environmental 
education focuses on youth developing the skills needed to make decisions and influence policy (Jensen and Schnack 1997). Similarly, parallel to the discussion of social learning within the context of hands-on monitoring and stewardship or civic ecology practices (Tidball and Krasny 2007, CCMN 2008), Krasny and Tidball (2009) describe civic ecology education, which occurs when young people and other novices become participants in hands-on resource stewardship activities alongside more experienced adults. Civic ecology practices that lend themselves to such "situated learning" include community gardening, watershed restoration, urban community forestry, wildlife habitat enhancement, and similar small-scale volunteer stewardship activities (Stone and Barlow 2007, Tidball and Krasny 2007). These action competence, civic ecology, and related educational approaches focus not only on individual learning but also on transforming social-ecological systems through participant engagement in authentic management decision making and practice (Emmons 1997, Hart 1997, Jensen and Schnack 1997, McClaren and Hammond 2005, Stone and Barlow 2007, Krasny and Tidball 2009, Schusler et al. 2009).

A group of learning theories that emphasize the interaction dimension of learning within social contexts, including situated learning (Rogoff and Lave 1984, Illeris 2007), activity theory (Engestrom 1987) and ecological views of learning (Barab and Roth 2006, Sterling 2007), is useful in understanding how learning occurs in programs where youth participate in local stewardship and natural resources management communities of practice (Wenger 1998, Armitage et al. 2008). In educational programs situated in watershed restoration, community forestry, and other civic ecology practices, adults act as facilitators of learning and as experienced practitioners in a civic ecology community of practice rather than as instructors. Youth in such programs start out as peripheral or novice participants, and through first observing and then working alongside the more experienced adults, eventually become full participants in the community of practice (Rogoff et al. 2003). Other authors, including Fusco (2001), Roth (2002), Roth and Lee (2004), Barab and Roth (2006), and Boyer and Roth (2006), have described education programs from a situated learning perspective, citing examples of youth engagement in civic ecology practices such as community gardening, harvesting seaweed, and habitat restoration.
Boyer and Roth (2006) use the term "heterogeneous environments" to draw attention to the messiness of learning situated in management practice relative to that which occurs in classrooms or museums, in terms of the participants, time span, environment within which learning takes place, tools used in learning, and intended products. Drawing from activity theory (Engestrom 1987), Roth (2002) uses the metaphor of fibers and a thread to describe such learning. The six fibers or elements include: the subjects (participants); objects (e.g., garden, watershed, or other social-ecological system that is the focus of stewardship practice); community (participants and the wider community impacted by their work); tools (e.g., pH meter); rules (e.g., respect for others and the environment); and division of labor (roles of participants and other community members). The thread is the learning or outcome of the activity, and can best be understood by looking not just at individual fibers, but rather as a property emerging from multiple interactions among fibers (Boyer and Roth 2006). For example, when a group of youth and adults (subjects) take on the task of creating a garden (object), the outcome or what they learn depends on the subjects and what tools they use (e.g., younger children may choose to plant flower seeds whereas older youth may want to measure soil $\mathrm{pH}$ ). By suggesting the need to adapt the use of tools depending on participants' interests and abilities, activity theory can be helpful in designing educational programs that integrate young people into ongoing adult resource stewardship or co-management initiatives.

Building on interactive learning theories and systems thinking, Greeno (1998), Barab and Roth (2006), and Chawla (2008) propose an "ecological view of learning," which emphasizes the interaction of effectivity sets, or individual participants' behaviors, with affordance networks, defined as the collection of facts, concepts, tools, practices, and people that are distributed across time and space and provide the context for learning. Examples of affordance networks include watershed restoration and other civic ecology initiatives that provide opportunities for participation and learning. Compared with authors describing social learning among adults, researchers focusing on youth education include more of an emphasis on participants' behaviors and abilities, and on the interaction of individual effectivity sets with aspects of the context in which learning takes place (Barab and Roth 2006). Furthermore, Chawla (2008) points out that learning occurs more effectively when the learner's environment changes in response to his or 
her action, and claims that reciprocity between selfproduced action and environmental events lies at the heart of development of a sense of competence or agency, which in turn leads to further action.

Within a learning activity system, an expansive cycle may emerge from a process that begins with the novice learning to do the task, moves to small innovations created as part of the learning, and then leads to transformation of the activity system itself (e.g., new rules or objects; Engestrom 1987). For example, youth and adults involved in an eel grass restoration project discovered new ways of measuring the grass; this innovation was shared among other participants, leading to more effective restoration practice (Roth and Lee 2004). A feedback loop may be used to describe how learning that leads to innovations in monitoring or restoration practices positively impacts the larger socialecological system, which in turn may provide more opportunities for learning. Similarly, positive feedback loops might be used to describe youth and adult capacity building. For example, adult gardeners who mentor younger participants may be motivated by the young people's interests in their gardening and subsequently become more active in community gardening, mentoring youth, and related community activities (Krasny and Tidball 2009). Thus, in addition to building human capacity, learning among youth may result in changing the environment (or context) in a manner reminiscent of the adult social learning feedbacks described by Pahl-Wostl et al. (2007).

\section{EDUCATION PROGRAM EXAMPLES}

We turn next to three program examples, two involving university students and one geared toward pre-college youth. Each example suggests possibilities for students learning about and fostering social-ecological resilience through participation in resource management and civic ecology practices.

\section{University Integrated Water Resource Management Course, Sweden}

In line with the paradigm shift taking place in water resources management in Europe, particularly with the recent unfolding of the Water Framework Directive (Blackmore et al. 2007a, Foundation for Water Research 2008), the Swedish University of
Agricultural Sciences adopted Integrated Water Resource Management (IWRM) as the theme for a 2-year Master's degree program starting in 2007. As a management practice, IWRM focuses on combining technologies, institutional strategies, and processes needed to facilitate the sustainable management of watersheds, rivers, and coastal waters in the face of conflicting demands. The stated aim of the Swedish University of Agricultural Sciences Master's program is to prepare students for the challenge of IWRM in Europe and the developing world. Below we describe the Stakeholding and Social Learning course offered in the first year of the program.

Underpinned by work in the SLIM project (Social Learning for the Integrated Management and Sustainable Use of Water at Catchment Scale, Blackmore et al. 2007a), social learning for this course is based on an epistemology that suggests knowledge is built through active engagement in defining and seeking improvements to complex environmental issues, rather than knowledge as fixed, expert-driven solutions to environmental problems. Social learning is defined as an interactive process for promoting collective and concerted action by multiple stakeholders to bring about systemic change (cf. Blackmore et al. 2007b, Ison et al. 2007).

Through his past work in education of agricultural and rural development professionals in Australia, the course instructor gained significant experience in systemic and experiential learning (Bawden et al. 1984, Wilson and Morren 1990, Sriskandarajah et al. 1991), which he has applied to his work in the water resources management program in Sweden. The course engages students in helping communities address complex social-ecological problems, which are often defined differently by various stakeholders. Thus, consistent with Midgely's (2000) work on systemic intervention, the course engages students in reflection on the conceptual boundaries of the system, the practice, and the problematic situation being studied, and of the process and research methodologies used to address the situation. Soft-systems methodology (Bunch 2003, Checkland and Poulter 2006), which attempts to foster learning and an understanding of diverse stakeholder perspectives through generating "rich pictures" and conceptual models of the selected systems, guides the approach to the overall intervention, providing both the methodology and much of the necessary toolbox. 
The Stakeholding and Social Learning course opens with an introduction to learning theories, stakeholding and stakeholders, and concepts in systems thinking and governance as applied to natural resource management contexts. The course then moves on to the field component, in which students are exposed to a real-life situation within water resource management with multi-stakeholder interests at play, and must develop a methodology for systemic intervention relevant to the chosen situation.

The restoration of Lake Tämnaren served as the case for the experiential component of the course in 2007. The Lake Tämnaren Water Council, which had been entrusted with responsibility for developing an action plan for local lake restoration incorporating multiple stakeholder interests, became the client for the students. Following an introductory session by the Chairman of the Water Council, the students defined themes for their inquiry and then undertook a reconnaissance trip of the Lake District, visiting the relevant local authorities, and holding over 20 separate meetings with a diverse range of stakeholders and interest groups. The whole class engaged in a discussion on the conceptual boundaries of the lake problem based on the multiple perspectives collected by different student groups and then developed several pictorial representations of the situation. Relevant themes and issues chosen at this stage were modeled as purposeful human activity systems, and comparison of these models with the real-world situation became the basis for debating changes that were both systemically desirable and culturally feasible. Because of the short duration of the course, the opportunity for interaction with the client group was limited, and resulted in only one significant iteration of the methodology cycle before the class facilitated a workshop for the members of the Water Council. During the workshop, the students employed a role play, poster presentations, group work by participants, and a feedback and evaluation session, and then compiled the study findings into a report for the clients. Each student also reflected on his or her learning in writing. The students were assessed on the basis of level of participation, reading assignments, oral presentations in class, and their reports and reflective writing. Despite the relatively short duration of the project, the clients acknowledged the usefulness of the students' pictorial representations of the complex water resource situation and of their recommendations for action.
Throughout the course, the students learned to maintain the balance between holding back in order to make reflective observations and deciding on the necessary action steps to be experimented with in collaboration with the clients. An understanding of Kolb's (1984) experiential learning cycle, in which learning is considered as the process of transforming experience into knowledge, and of Checkland and Poulter's (2006) soft-systems methodology helped the instructor move learners beyond superficial learning-by-doing toward deeper reflection on the situation in the field, on the process used to address management issues, and on relevant theoretical and conceptual frameworks.

\section{Garden Mosaics, USA}

Garden Mosaics is an environmental science and civic ecology education program in which learning is situated in urban community gardening practices (www.gardenmosaics.org). Youth learn alongside adult community gardeners, who share with youth their knowledge of plants and how plants connect to the gardeners' cultures and traditions. Many of the gardeners in urban community gardens in the USA are African-Americans or immigrants from developing countries who have adapted farming practices acquired in rural settings to small gardens in highly urbanized neighborhoods. As sites where people reconnect with nature, share stories, socialize with family and friends, grow food and flowers, host cultural events such as concerts and celebrations, and get exercise (Schmelzkopf 1995, Saldivar and Krasny 2004), these gardens provide multiple ecosystem services, including the provisioning service of food, supporting services such as soil formation, and aesthetic, recreational, and educational cultural services. These ecosystem services in turn lead to such constituents of wellbeing as nutritious food, personal safety, feeling well, social cohesion, and ability to help others (cf. Millennium Ecosystem Assessment (MA) 2005). In addition to fostering ecosystem services, community gardening fosters multiple attributes of resilient systems, through integrating biological and cultural diversity, practice-based knowledge of gardeners and scientific knowledge of researchers, participatory action, flexible social institutions, and adaptive learning (Tidball and Krasny 2007, King 2008).

Youth in Garden Mosaics garden alongside experienced adults within a community context, and learn about ecology and agriculture through short- 
term inquiry activities; they conduct investigations in which they explore questions about social and ecological components of the garden and neighborhood and conduct action projects to enhance the garden and neighborhood (Fig. 1). For the adult community gardeners, sharing their experiences and knowledge with youth provides opportunities for community engagement and feelings of recognition beyond those provided by gardening with other adults (Krasny and Tidball 2009).

In addition to learning about urban socialecological systems, through their action projects, youth engage in learning that fosters environmental quality and community well-being. Given that maintaining ecosystem services is a critical dimension of resilience (Walker et al. 2002), if the youth's action projects enhance the ability of the garden or neighborhood to provide such services (e. g., food or recreational opportunities, MA 2005), then they contribute to practices fostering resilience in their local community. By working with, learning from, and respecting the knowledge of immigrant and other gardeners, the young people may be engaging in learning that further enhances resilience, through integrating multiple forms of knowledge, as well as by building trust, social connections, associational involvement, volunteerism, and other dimensions of social capital (Putnam 1995, Pahl-Wostl et al. 2007).

\section{Urban Environments Service-Learning Course, USA}

The Cornell University Urban Environments service-learning course is intended to be a broad survey of urban environmental and natural resources challenges seen through the lenses of urban environmental justice, urban sustainability, and social-ecological systems resilience (http://ww w.sci-links.com/urbanenvironments.html). The course includes a weekly seminar and service-learning experience in Ithaca, New York throughout the semester, and a 1-week service-learning experience in New York City. It features five modules, each of which integrates civic ecology theoretical perspectives and practice, including urban horticulture and community gardening, urban forestry, urban wildlife, urban fisheries, and green architecture and landscaping.
According to Eyler and Giles (1999), servicelearning occurs through a cycle of action and reflection as students work with others to apply classroom learning to community problems, and reflect on their experience to achieve deeper understanding and skills. The Urban Environments service-learning class incorporates the following components: (1) classroom discussions about civic ecology and urban social-ecological systems and resilience; (2) service-related activities in collaboration with civic ecology partner sites; and (3) intentional reflections or analysis of servicerelated observations and experiences (commonly called journaling, or in our case blogging). The service-related activities include community gardening, tree planting, and wildlife habitat assessment, and are conducted alongside NGO and city agency staff, community activists, and volunteers. The praxis implications of servicelearning are reinforced through the journaling, wherein learners are encouraged to connect the theoretical content with their real-world service activities.

The course philosophy stems from a recognition that whereas cities are critical to regional and global sustainability and security (Tidball et al. 2008), discussion among natural resources managers and researchers too often focuses on the negative environmental impacts of urbanization. As an alternative, the course tries to help the undergraduate students develop an appreciation for assets within urban communities and of the potential for urban human, social, financial, and natural capital to be harnessed as a force for ecological restoration. Students also discover portals into Aldo Leopold's land ethic (Leopold 1949, 2004) for urban dwellers.

By integrating learning about resilience in complex urban social-ecological systems with service learning and reflection, the course explores the type of training that is needed for the next generation of natural resources professionals and citizen stakeholders to understand and foster urban resilience. A diagram depicting the processes and structures involved in urban resilience is used in teaching about resilience (Fig. 2). A second conceptual model is used in the class to depict the process by which the students' service-learning projects might contribute toward resilience of the urban system (Fig. 3). 
Fig. 1. Garden Mosaics learning activities.

Youth activities, including $i \cdot m$ science investigations, Action Projects, and other shorter-term learning exercises, build on scientific and practice-based knowledge, and civic values in community gardens.

\section{ims science investigations}

- Neighborhood Exploration. Youth explore the assets of their community using spatial imagery, and observations and interviews conducted while walking around their neighborhood.

- Gardener Story. Youth interview a gardener about the connections between planting practices and cultural traditions.

- Community Garden Inventory. Participants list the activities and other services community gardens provide for their neighborhood.

- Weed Watch. Participants collect data about weed problems and control methods in urban gardens.

Action Projects. Youth apply what they have learned in their $i \cdot m$ science investigations to enhancing their neighborhood or local gardens. Example Action Projects include youth conducting a neighborhood garden festival, donating produce to food kitchens, creating a plant sculpture in a garden, sharing what they have learned with younger children, and creating new community gardens.

Short-term inquiry and other learning activities ranging from jeopardy games focused on food crops to blog exchanges with youth overseas.

(Krasny et al. 2005, 2006)

By embedding learning in multiple civic ecology practices, and thus helping to maintain the supply of ecosystem services, creating platforms for sharing knowledge, and fostering ties among university student, community, and government stakeholders, the Urban Environments course may contribute to social-ecological resilience. Building on the active service-learning component, the reflective component of the Urban Environments course also attempts to engage students in questioning how they frame natural resources problem, or multiple loop learning (Marquardt Arévalo et al. 2009). In reading the students' journals or blogs, one gets the sense that the students, many of whom come from New York City and other urban areas, feel conflicted. On the one hand, they want to be loyal to their cities and neighborhoods, but on the other hand, they are aware that cities generally are thought of as "antinatural" compared with more pristine environments. This tension creates an opportunity for students not 
Fig. 2. Classroom learning about resilience. Urban resilience concepts explored in the Urban Environments class. Source: Resilience Alliance website. [online] URL: http://www.resalliance. org/1610.php.

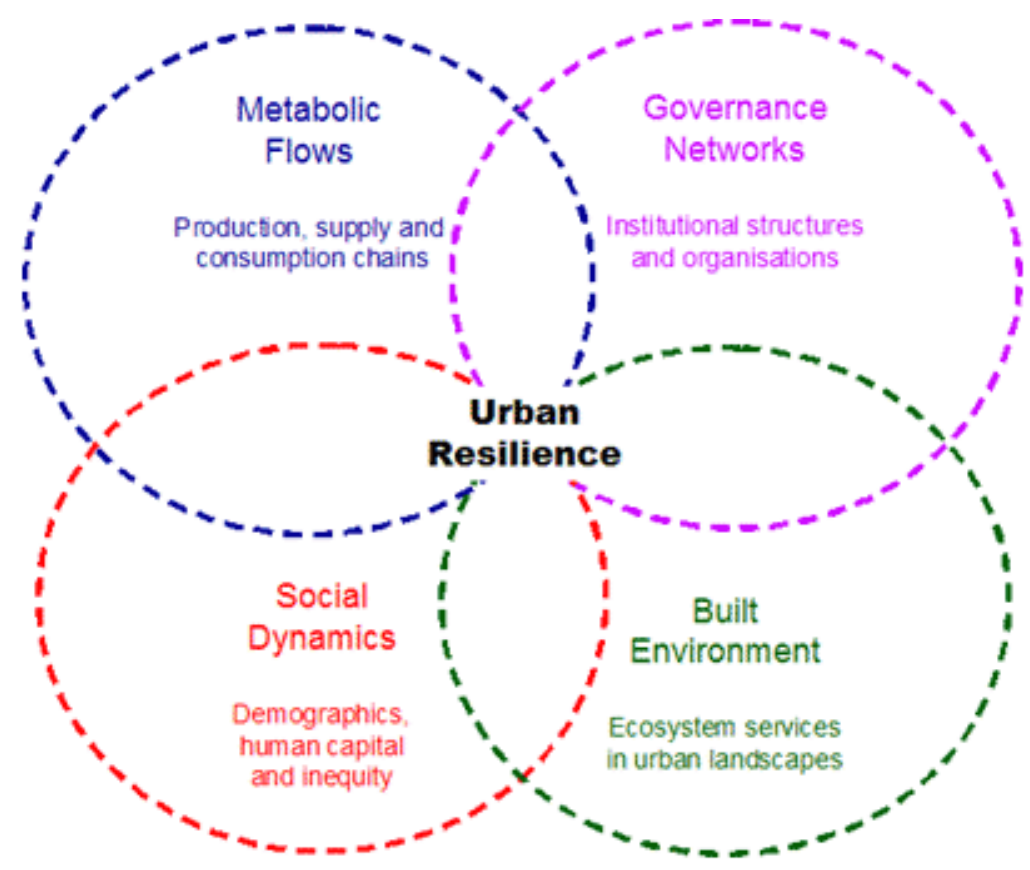

only to learn collaboratively about urban ecology and resilience, but also to learn about how humans can be a part of and enhance the resilience of an urban social-ecological system. As participants reflect on, question, and transform their assumptions about urban systems, they engage in double-loop learning. Were such knowledge sharing and higher-order learning to continue, it could in turn lead to tighter feedbacks (Walker et al. 2002), as students and stakeholders question the rules of urban resource management, seek to understand why a particular practice works better than others, and then act on their new understanding.

\section{DISCUSSION}

In all three educational examples described above, learning is situated in adaptive co-management or civic ecology practices, which by catalyzing community assets that foster environmental quality and social well-being may contribute to resilience of the local watershed or urban neighborhood. By becoming nested in existing adaptive co- management and civic ecology feedback loops, the educational programs themselves also may contribute to resilience in these local systems. Thus, the examples offer insight into how situated learning as described in the environmental and science education literatures (Illeris 2007) may contribute to social learning addressing complex management issues in social-ecological systems (Blackmore et al. 2007a, Pahl-Wostl et al. 2007, 2008).

The three program examples also open up questions about how younger stakeholders might become involved in natural resources management and about the learning outcomes that may transpire through their involvement. In the Swedish graduate course, Masters students exhibited social learning through their engagement in a watershed resource dilemma (Blackmore 2007, Blackmore et al. 2007a) both as participants and as facilitators. In the two U. S. examples, the educational experiences were conceived of first as a learning experience for individual students situated in and contributing to ongoing civic ecology practice, rather than as opportunities to prepare students to facilitate adult 
Fig. 3. Ecological service learning to foster resilience: feedback loops depicting the relationships among ecological service learning and social and ecosystem resilience. Starting on the right with the smaller feedback loop (A), ecological or environmental service learning fosters social system health and resilience; more service learning leads to more social system health and resilience, which in turn leads to more ecological service learning and so on. The larger feedback loop (B) shows how ecological service learning or civic ecology practice (e.g., community tree planting) enhances the urban forest, which in turn maintains ecosystem services. These ecosystem services contribute to and enhance social system health and resilience, which may spawn additional civic ecology practice and ecological service learning. (Diagram draws from work of Kuo et al. 1998, Miles et al. 1998, Kuo and Sullivan 2001, Wells and Evans 2003, Wells and Lekies 2006, and Resilience Alliance 2008).

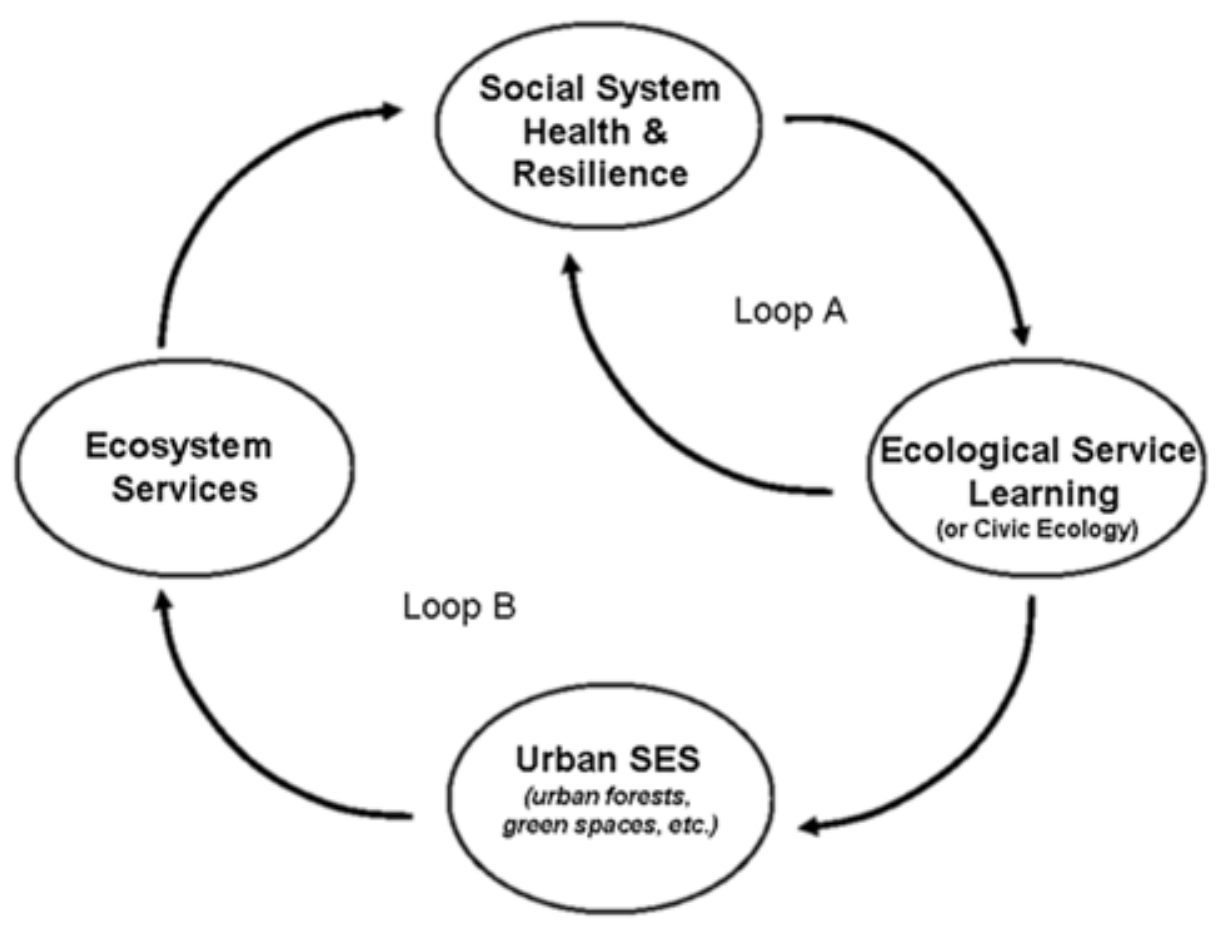

stakeholders addressing larger-scale management issues. However, similar to the Swedish example, opportunities for social learning among the group of students aimed at enhancing environmental quality emerged through the Garden Mosaics action projects and the Urban Environments servicelearning projects. Unlike Garden Mosaics, in which the learning took place in gardens and out-of-school youth programs, both the Swedish watershed and the Urban Environments courses incorporated classroom and writing components with a specific focus on reflection, and thus may have had a greater potential for stimulating higher loop and adaptive learning. The examples also provided opportunities for students to build individual knowledge and skills related to science and civic participation (Melchior and Bailis 2003, Roth and Desautels 2004, Roth and Lee 2004, Schusler and Krasny 2008). Finally, consistent with recent literature in environmental education, all three programs suggest a broadening in emphasis from individual outcomes such as environmental behaviors, attitudes, and understandings (e.g., Hungerford et al. 2001) and academic achievement (Ernst and Monroe 2004) to encompass environmental quality (Cline et al. 2002, Duffin et al. 2007, Short 2007; B. Johnson, Antioch 
University, unpublished manuscript) and community outcomes such as social capital (Jarrett et al. 2005).

In addition to examining the learning processes and outcomes, we use the Swedish and U.S. education examples to highlight the interactions of education with other social and ecological components of the system, and thus to suggest a systems perspective or ecology of environmental education (Tidball and Krasny 2009). Such a perspective recognizes recursive rather than linear relationships among educational programs and the social-ecological systems in which they are embedded, and suggests that both education and society are engaged in ongoing mutual transformations (Sterling 2003).

Building on Sterling's (2003) work, we propose future studies to examine how education at the precollege and university levels interacts with other social-ecological system components. These interactions might be in the form of positive feedback loops, as could be the case when education is situated in and expands on a civic ecology practice. For example, in Garden Mosaics, young people not only become community gardeners themselves, but through their interest in the work of more experienced gardeners, may also encourage the adults to get further involved, resulting in an expansion of the civic ecology practice. Or, as in the Urban Environments service-learning course, education may be nested within existing feedbacks in which civic ecology practices enhance biophysical aspects of the environment, which in turn feed back to enhance the health of individuals and social systems (Figs. 3, 4).

\section{CONCLUSION}

Consistent with Masten and Obradovic's (2008) call for research examining resilience at multiple levels, situated learning theory suggests paths for integrating individual learning in environmental and science education with social learning in natural resources management. The emphasis of situated learning theorists is on learning as "an ecological, not an individualistic, phenomenon that is distributed and enables the learner to engage in progressively more adaptive individual-environment relations" (Barab and Roth 2006, p. 8). Both the situated and social learning literatures focus on learning contexts, participation in communities of practice, and feedback loops through which learning leads to positive impacts on the learner, individuals with whom he or she interacts, and the context or social-ecological system in which learning takes place (Barab and Roth 2006, Chawla 2008, PahlWostl et al. 2007, Armitage et al. 2008). At the same time, differences between the two literatures exist, with social learning focusing more on the contribution of learning to adaptive resource management and to resilient social-ecological systems, and situated views of learning and education focusing on how to create environments that foster individual learning and transformation. These differences are not surprising given that social learning theory within management contexts emerges from ecology and natural resources disciplines, and situated theories of youth learning often emerge from a starting point of science education and student achievement. Integrating these different perspectives can spur innovative educational practices, such as using situated and activity learning theories to inform programs that prepare students to facilitate adaptive comanagement, and applying social learning theory to expand environmental education goals to encompass adaptive co-management outcomes. Such integration also offers guidance for developing educational programs in which students participate in environmental stewardship activities and social learning and that lead to personal transformations and changes in the larger social-ecological system.

Whereas education in school classrooms often is based on the notion of transmission of information from the teacher to student, many education scholars, including those focusing on service learning, experiential learning, and situated learning, have suggested ways in which education can engage students in resource stewardship and policy and in reflecting on their activities so as to foster higher-oop learning. Such activities and reflection can be carried on within an adaptive comanagement or civic ecology context that integrates environmental and social values, and can be used to help prepare students to facilitate participatory forms of management. Thus, this paper suggests the potential of university and secondary education to engage younger learners in social learning and comanagement processes alongside adult civic ecologists and other resource stakeholders. For educators, a social-ecological system resilience framework challenges us to look beyond contentdriven approaches, to consider outcomes in addition to those at the level of the individual, and to examine 
Fig. 4. Education, civic ecology practice, and social-ecological system resilience. Series of figures showing how an educational program embedded within civic ecology practice, along with the civic ecology practice itself, can confer social-ecological system resilience. (a) A traditional view of education emphasizes its role in producing greater understanding of a predetermined body of knowledge. (b) Civic ecology practice enhances natural capital (e.g., through planting trees), which in turn produces ecosystem services (e.g., carbon sequestration, recreation). By community members working together to restore degraded sites, civic ecology practice also fosters social capital. Feedback loops exist between natural and social capital, as when more trees in a community provide sites for people to gather and socialize, and people who are connected socially plant more trees. Such practices occur within a larger social-ecological system and have implications for the resilience of that system. (c) What happens if instead of education being a stand alone system, it becomes embedded within a civic ecology practice? (d) Together, the educational program and the civic ecology practice foster human, natural, and social capital. Furthermore, additional feedback loops are generated among human, natural, and social capital. Human capital, now conceived of as adaptive learning, contributes directly to natural capital (as when youth learn more effective methods for planting trees), and natural capital contributes to human capital (e.g., by providing opportunities for learning about nature). Similarly, social capital can provide opportunities to build human capital (as when adults who are working together incorporate younger people in their civic ecology practice), and youth learning from the adult civic ecologists can build not only human capital but also social capital among the youth and adults. (Not shown in (d) relationship between natural and social capital depicted in (c) also persists.) (e) Civic ecology practice provides a setting for educational programs. An educational program situated in a civic ecology practice produces human capital by helping young people acquire skills and become adaptive learners. Such human capital enables young people to contribute to the civic ecology practice, forming a reinforcing feedback loop. The civic ecology practice, together with the education program, foster attributes of resilient systems, and thus become a source of social-ecological system resilience.(Diagram draws from work of from Folke et al. 2002, Walker and Salt 2006, and Krasny and Tidball 2009).

(a)
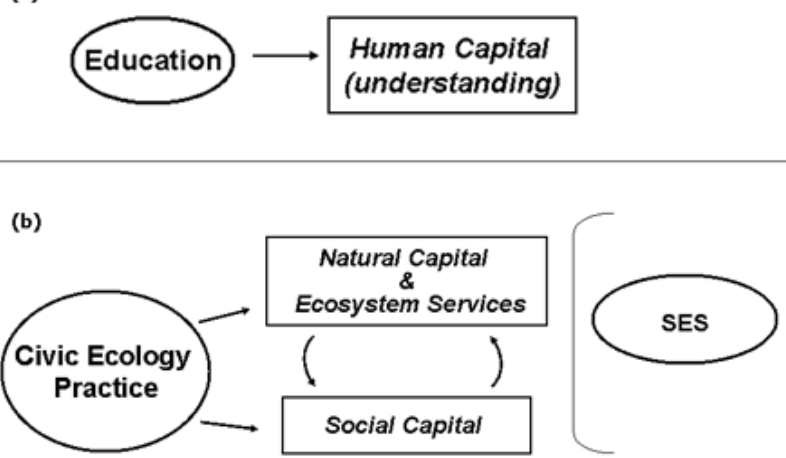

(c)

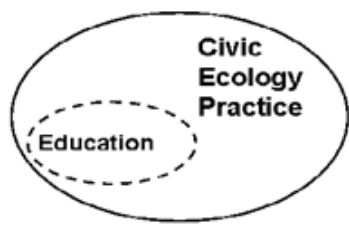

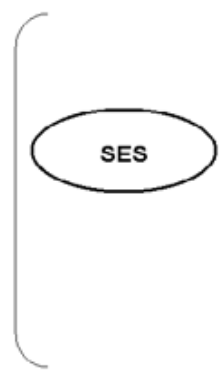

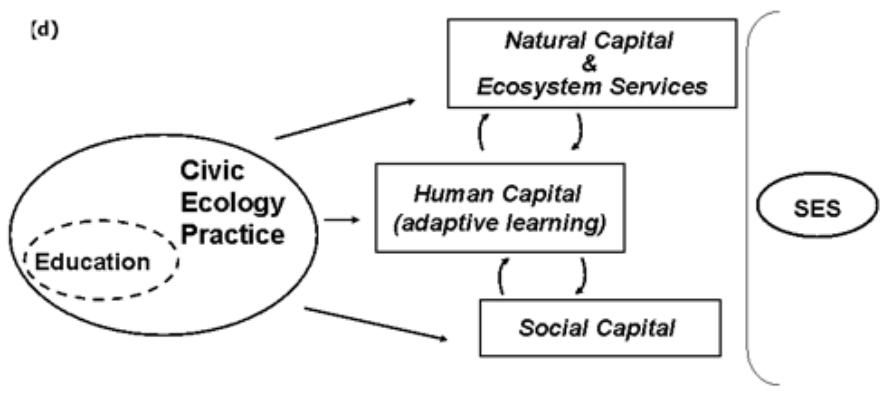

(e)

Resilience Attributes

Natural capital

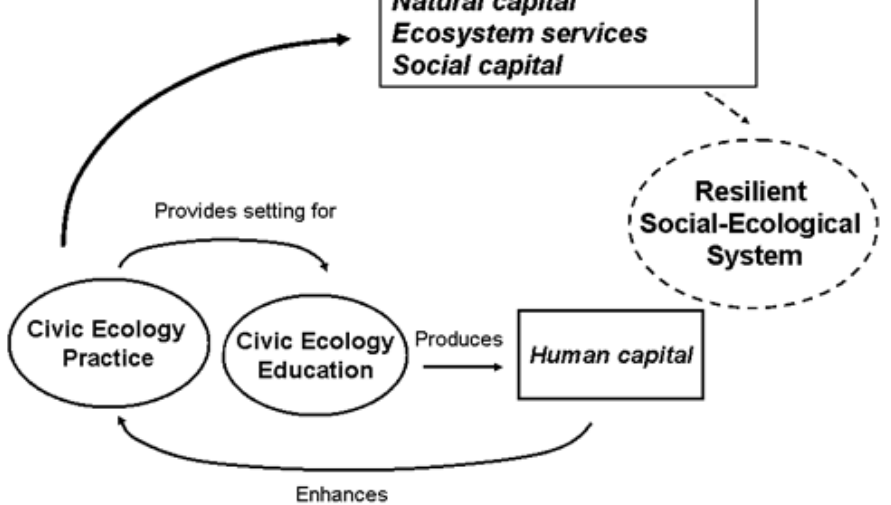


interactions between individual learners, educational programs, and other components of the broader social-ecological system. Finally, for resilience scholars, this paper may represent an initial step in suggesting commonalities among systems views of individual learning and education, and systems perspectives applied to social-ecological resilience.

Responses to this article can be read online at: http://www.ecologyandsociety.org/voll4/iss2/art38/ responses/

\section{Acknowledgments:}

The authors thank Ryan Plummer, Stephen Sterling, Alexey Kudryavtsev, and an anonymous reviewer. The work reported in this paper received support from the National Science Foundation Informal Science Education Program (ESI 0125582), the Sustainable Agriculture Research and Education program of the U.S. Department of Agriculture, Cornell University Public Service Center, and the U.S. Department of Agriculture Federal Formula Funds program.

\section{LITERATURE CITED}

Armitage, D., M. Marschke, and R. Plummer. 2008. Adaptive co-management and the paradox of learning. Global Environmental Change 18:86-98.

Barab, S. A., and W.-M. Roth. 2006. Curriculumbased ecosystems: supporting knowing from an ecological perspective. Educational Researcher 35 (5):3-13.

Bawden, R. J., R. D. Macadam, R. J. Packham, and I. Valentine. 1984. Systems thinking and practices in the education of agriculturalists. Agricultural Systems 13(4):205-225.

Benbasat, J. A., and C. Gass. 2001. Reflections on integration, interaction, and community: the Science One Program and beyond. Conservation Ecology 5(2): 26. [online] URL: http://www.consec ol.org/vol5/iss2/art26/.
Berkes, F. 2004. Knowledge, learning and the resilience of social-ecological systems. Pages 1-17 in The commons in an age of global transition: challenges, risks and opportunities. Proceedings of the Tenth Conference of the International Association for the Study of Common Property, 913 August 2004, Oaxaca, Mexico. [online] URL: http://dlc.dlib.indiana.edu/dlc/handle/123456789/2385

Berkes, F., D. Armitage, and N. Doubleday. 2007. Synthesis: adapting, innovating, evolving. Pages 308-327 in F. Berkes, D. Armitage, and N. Doubleday, editors. Adaptive co-management: collaboration, learning, and multi-level governance. University of British Columbia Press, Vancouver, British Columbia, Canada.

Blackmore, C. 2007. What kinds of knowledge, knowing, and learning are required for addressing resource dilemmas?: a theoretical overview. Environmental Science and Policy 10:512-525.

Blackmore, C., R. Ison, and J. Jiggins, editors. 2007a. Social learning: an alternative policy instrument for managing in the context of Europe's water. Environmental Science and Policy 10 (6):499-586.

Blackmore, C., R. Ison, and J. Jiggins. 2007b. Social learning: an alternative policy instrument for managing in the context of Europe's water (Editorial). Environmental Science and Policy 10 (6):493-498.

Bowers, C. A. 2002. Toward an eco-justice pedagogy. Environmental Education Research 8 (1):21-34.

Boyer, L., and W.-M. Roth. 2006. Learning and teaching as emergent features of informal settings: an ethnographic study in an environmental action group. Science Education 90:1028-1049.

Bunch, M. 2003. Soft systems methodology and the ecosystem approach: a system study of the Cooum River and environs in Chennai, India. Environmental Management 31(2):182-197.

Canadian Community Monitoring Network (CCMN). 2008. Canadian Community Monitoring Network. Lessons learned. CCMN, Burlington, 
Ontario, Canada. [online] URL: http://www.ccmn.ca/ english/lessons learned.html.

Chawla, L. 2008. Participation and the ecology of environmental awareness. Pages 98-110 in A. Reid, B. B. Jensen, and J. Nikel, editors. Participation and learning: perspectives on education and the environment, health and sustainability. SpringerVerlag, New York, New York, USA.

Checkland, P., and J. Poulter. 2006. Learning for action: a short definitive account of soft systems methodology and its use for practitioners, teachers and students. Wiley, London, UK.

Cline, S., L. Cronin-Jones, C. Johnson, M. Hakverdi, and R. Penwell. 2002. The impact of community involvement on the success of schoolyard ecosystem restoration/education programs: a case study approach. American Education Research Association Annual Meetings, New Orleans, Louisiana, USA.

Duffin, M., M. Murphy, and B. Johnson. 2007. Quantifying a relationship between place-based learning and environmental quality. Presentation at North American Association for Environmental Education Research Symposium. Virginia Beach Virginia, USA.

Emmons, K. M. 1997. Perspectives on environmental action: reflection and revision through practical experience. Journal of Environmental Education 29:34-44.

Engestrom, Y. 1987. Learning by expanding: an activity-theoretical approach to developmental research. Orienta-Konsultit, Helsinki, Finland.

Ernst, J., and M. C. Monroe. 2004. The effects of environment-based education on students' critical thinking skills and disposition toward critical thinking. Environmental Education Research 10 (4):507-522.

Eyler, J., and D. E. Giles. 1998. Where's the learning in service-learning? Jossey-Bass Publishers, Indianapolis, Indiana, USA.

Fernandez-Gimenez, M. E., H. L. Ballard, and V. E. Sturtevant. 2008. Adaptive management and social learning in collaborative and communitybased monitoring: a study of five community-based forestry organizations in the western USA. Ecology and Society 13(2): 4. [online] URL: http://www.eco logyandsociety.org/vol13/iss2/art4/.

Fien, J., editor. 1993. Education for the environment. Deakin University, Geelong, Australia.

Folke, C. 2006. Resilience: the emergence of a perspective for social-ecological systems analyses. Global Environmental Change 16:253-267.

Folke, C., S. Carpenter, T. Elmqvist, L. Gunderson, C. S. Holling, B. Walker, J. Bengtsson, F. Berkes, J. Colding, K. Danell, M. Falkenmark, L. Gordon, R. Kasperson, N. Kautsky, A. Kinzig, S. Levin, K.-G. Mäler, F. Moberg, L. Ohlsson, P. Olsson, E. Ostrom, W. Reid, J. Rockström, H. Savenije, and U. Svedin. 2002. Resilience and sustainable development: building adaptive capacity in a world of transformations. 16 April 2002, World Summit on Sustainable Development, Johannesburg, South Africa.

Foundation for Water Research. 2008. Water framework directive information centre. [online] URL: http://www.euwfd.com/.

Fusco, D. 2001. Creating relevant science through urban planning and gardening. Journal of Research in Science Teaching 38(8):860-877.

Galindo-Leal, C. 2001. Design and analysis of conservation projects in Latin America: an integrative approach to training. Conservation Ecology 5(2): 16. [online] URL: http://www.consec ol.org/vol5/iss2/art16/.

Greeno, J. G. 1998. The situativity of knowing, learning, and research. American Psychologist $\mathbf{5 3}$ (1):5-26.

Gunderson, L. H. 2001. South Florida: the reality of change and the prospects for sustainability: managing surprising ecosystems in southern Florida. Ecological Economics 37(3):371-378.

Gunderson, L. H., S. R. Carpenter, C. Folke, P. Olsson, and G. D. Peterson. 2006. Water RATs (resilience, adaptability, and transformability) in lake and wetland social-ecological systems. Ecology and Society 11(1): 16. [online] URL: http: //www.ecologyandsociety.org/vol11/iss1/art16/. 
Gunderson, L.H. and C. S. Holling, editors. 2002. Panarchy: understanding transformations in human and natural systems. Island Press, Washington D.C., USA.

Hake, R. 2002. Lessons from the physics education reform effort. Conservation Ecology 5(2):28. [online] URL: http://www.consecol.org/vol5/iss2/art28/

Hart, R. A. 1997. Children's participation: the theory and practice of involving young citizens in community development and environmental care. Earthscan Publications, London, UK.

Hungerford, H. R., W. J. Bluhm, T. L. Volk, and J. M. Ramsey. 2001. Essential readings in environmental education. Second Edition. Stipes Publishing, LLC, Champaign, Illinois, USA.

Illeris, K. 2007. How we learn: learning and nonlearning in school and beyond. Routledge, London, UK.

Ison, R., N. Roling, and D. Watson. 2007. Challenges to science and society in the sustainable management and use of water: investigating the role of social learning. Environmental Science and Policy 10:499-511.

Jarrett, R. L., P. J. Sullivan, and N. D Watkins. 2005. Developing social capital through participation in organized youth programs: qualitative insights from three programs. Journal of Community Psychology 33(1):41-55.

Jensen, B. B., and K. Schnack. 1997. The action competence approach in environmental education. Environmental Education Research 3(2):163-178.

King, C. A. 2008. Agri-ecological systems and resilience. Systems Research and Behavioral Science 25:11-124.

Kolb, D.A. 1984. Experiential learning: experience as the source of learning and development. Prentice Hall, Inc., Englewood Cliffs, New Jersey, USA.

Krasny, M. E., and R. Bonney. 2005. Environmental education through citizen science and participatory action research: the Cornell Laboratory of Ornithology and Garden Mosaics examples. Pages 292-319 in M. Mappin and E. A.
Johnson, editors. Environmental education or advocacy: perspectives of ecology and education in environmental education. Cambridge University Press, Cambridge, UK.

Krasny, M. E., R. Doyle, K.G. Tidball, and the Garden Mosaics Leadership Team. 2005. Garden Mosaics Program manual. Cornell University Department of Natural Resources, Ithaca, New York, USA.

Krasny, M. E., and K. G. Tidball. 2009. Applying a resilience systems framework to urban environmental education. Environmental Education Research, in press.

Krasny, M. E., K. G. Tidball, and N. Najarian. 2006. Garden Mosaics website. [online] URL: ww w.gardenmosaics.org.

Kuo, F. E., and W. C. Sullivan. 2001. Environment and crime in the inner city: Does vegetation reduce crime? Environment and Behavior 33:343-367.

Kuo, F. E., W. C. Sullivan, R. L. Coley, and L. Brunson. 1998. Fertile ground for community: inner-city neighborhood common spaces. American Journal of Community Psychology 26(6):823-851.

Lave, J., and Wenger, E.. 1991. Situated learning. Cambridge University Press, Cambridge, UK.

Leopold, A. 1949. A Sand County almanac. Oxford University Press, New York, New York, USA.

Leopold, A. C. 2004. Living with the land ethic. Bioscience 54:149-154.

Marquardt Arévalo K., Ljung M. and Sriskandarajah, N. 2009. Learning through feedback in the field: an example of a reflective learning NGO in the Peruvian Amazon. Action Research, in press.

Marschke, M., and A. J. Sinclair. 2009. Learning for sustainability: participatory resource management in Cambodian fishing villages. Journal of Environmental Management 90(1):206-216.

Masten, A. S., and J. Obradovic. 2008. Disaster preparation and recovery: lessons from research on resilience in human development. Ecology and Society 13(1): 9. [online] URL: http://www.ecology andsociety.org/vol13/iss1/art9/. 
McClaren, M., and B. Hammond. 2005. Integrating education and action in environmental education. Pages 267-291 in E. A. Johnson and M. J. Mappin, editors. Environmental education and advocacy: changing perspectives of ecology and education. Cambridge University Press, Cambridge, UK.

Melchior, A., and L. N. Bailis. 2003. 2001-2002 Earth Force evaluation: program implementation and impacts. Center for Youth and Communities, Heller Graduate School, Brandeis University, Waltham, Massachusetts, USA.

Midgley, G. 2000. Systemic intervention: philosophy, methodology and practice. Kluwer Academic/Plenum Publishers, Dordrecht, The Netherlands.

Miles, I., W. Sullivan, and F. Kuo. 1998. Ecological restoration volunteers: the benefits of participation. Urban Ecosystems 2:27-41.

Millennium Ecosystem Assessment (MA). 2005. Ecosystems and human well-being: synthesis. Island Press, Washington, D.C., USA.

Moll, L. C., C. Amanti, D. Neff, and N. Gonzalez. 1992. Funds of knowledge for teaching: using a qualitative approach to connect homes and classrooms. Theory into Practice 31(2):132-141.

Mostert, E., C. Pahl-Wostl, Y. Rees, B. Searle, D. Tabara, and J. Tippett. 2007. Social learning in European river-basin management: barriers and fostering mechanisms from 10 river basins. Ecology and Society 12(1): 19. [online] URL: http://www.e cologyandsociety.org/vol12/iss 1/art19/.

National Research Council (NRC). 1996. National science education standards. The National Academies Press, Washington, D.C., USA.

Niewolny, K., and A. L. Wilson. 2009. What happened to the promise? A critical (re)orientation of two sociocultural learning traditions. Adult Education Research, in press.

Olsson, P., C. Folke, and F. Berkes. 2004. Adaptive co-management for building resilience in social-ecological systems. Environmental Management 34:75-90.
Pahl-Wostl, C., M. Craps, A. Dewulf, E. Mostert, D. Tabara, and T. Taillieu. 2007. Social learning and water resources management. Ecology and Society 12(2): 5. [online] URL: http://www.ecology andsociety.org/vol12/iss2/art5/.

Pahl-Worstl, C., D. Tabara, R. Bouwen, M. Craps, A. Dewulf, E. Mostert, D. Ridder, and T. Taillieu. 2008. The importance of social learning and culture for sustainable water management. Ecological Economics 64:484-495.

Plummer, R., and J. FitzGibbon. 2008. Connecting adaptive co-management, social learning, and social capital through theory and practice. Pages 38-61 in F. Berkes, D. Armitage, and N. Doubleday, editors. Adaptive comanagement: collaboration, learning, and multilevel governance. University of British Columbia Press, Vancouver, British Columbia, Canada.

Putnam, R. B. 1995. Bowling alone: America's declining social capital. Journal of Democracy 6 (1):65-78.

Resilience Alliance. 2008. Resilience Alliance website. [online] URL: http://www.resalliance.org/1. php.

Rogoff, B., and J. Lave, editors. 1984. Everyday cognition: its development in social context. Harvard College, Cambridge, Massachusetts, USA.

Rogoff, R., R. Paradise, R. Mejia Arauz, M. Correa-Chavez, and C.Angellilo. 2003. Firsthand learning through intent participation. Annual Review of Psychology 54:175-203.

Roth, W.-M. 2002. Aprender ciencia en y para la comunidad [Learning science in and for the community]. Ense-anza de las Ciencias 20(2):195208.

Roth, W. M., and J. Désautels. 2004. Educating for citizenship: reappraising the role of science education. Canadian Journal for Science, Mathematics and Technology Education 4(2):149168.

Roth, W.-M., and S. Lee. 2004. Science education as/for participation in the community. Science Education 88:263-291. 
Saldivar, L., and M. E. Krasny. 2004. The role of NYC Latino community gardens in community development, open space, and civic agriculture. Agriculture and Human Values 21:399-412.

Schmelzkopf, K. 1995. Urban community gardens as contested spaces. Geographical Review $\mathbf{8 5}$ (3):364-381.

Schusler, T. M., D. J. Decker, and M. J. Pfeffer. 2003. Social learning for collaborative natural resource management. Society and Natural Resources 15:309-326.

Schusler, T. M., and M. E. Krasny. 2008. Youth participation in local environmental action: developing political and scientific literacy. Pages 268-284 in A. Reid, B. B. Jensen, J. Nikel, and V. Simovska, editors. Participation and learning: perspectives on education and the environment, health and sustainability. Springer, New York, New York, USA.

Schusler, T. M., M. E. Krasny, S. Peters, and D. J. Decker. 2009. Developing citizens and communities through youth environmental action. Environmental Education Research, in press.

Short,P. C. 2007. Use of the Oslo-Potsdam Solution to test the effect of an environmental education model on tangible measures of environmental protection. Dissertation, Southern Illinois University, Carbondale, Illinois, USA.

Silverman, H. 2008. Citizen science and social learning. People and Place 1(1). [online] URL: htt p://www.peopleandplace.net/perspectives/44.

Sriskandarajah, N., R. J. Bawden, and R. G. Packham. 1991. Systems agriculture: a paradigm for sustainability. Association of Farming Systems Research-Extension Newsletter 2(3):1-5.

Sterling, S. 2003. Whole systems thinking as a basis for paradigm change in education: explorations in the context of sustainability. Dissertation, University of Bath, Bath, UK.

Sterling, S. 2007. Riding the storm: towards a connective cultural consciousness. Pages 63-82 in A. Wals, editor. Social learning towards a more sustainable world: principles, perspectives, and praxis. Wagengingen Academic Press, Wagengingen, The Netherlands.

Stone, M., and Z. Barlow. 2007. Social learning in the STRAW project. Pages 405-419 in A. Wals, editor. Social learning towards a more sustainable world: principles, perspectives, and praxis. Wagengingen Academic Press, Wagengingen, The Netherlands.

Tidball, K. G., and M. E. Krasny. 2007. From risk to resilience: what role for community greening and civic ecology in cities? Pages 149-164 in A. Wals, editor. Social learning towards a more sustainable world: principles, perspectives, and praxis. Wagengingen Academic Press, Wagengingen, The Netherlands.

Tidball, K. G., and M. E. Krasny. 2009. An ecology of environmental education. World Environmental Education Conference, Montreal, Quebec, Canada, in press.

Tidball, K. G., E. D. Weinstein, S. Kaisler, R. Grossman-Vermaas, and S. Tousley. 2008. Stakeholder asset-based planning environment. DOD/ OSD 2007 STTR TOPIC 003 Final Technical Report, U.S. Department of Defense, Washington, D.C., USA.

Walker, B., S. R. Carpenter, J. Anderies, N. Abel, G. S. Cumming, M. Janssen, L. Lebel, J. Norberg, G. D. Peterson, and R. Pritchard. 2002. Resilience management in social-ecological systems: a working hypothesis for a participatory approach. Conservation Ecology 6(1): 14. [online] URL: http://www.ecologyandsociety.org/vol6/iss1/ $\underline{\operatorname{art14}}$.

Walker, B. H., L. H. Gunderson, A. P. Kinzig, C Folke, S. R. Carpenter, and L. Schultz. 2006. A handful of heuristics and some propositions for understanding resilience in social-ecological systems. Ecology and Society 11(1): 13. Available [online] URL: http://www.ecologyandsociety.org/voll1/ iss1/art13/.

Walker, B. H., and D. Salt. 2006. Resilience thinking: sustaining ecosystems and people in a changing world. Island Press, Washington, D.C., USA. 
Wals, A. E. J., F. Geerlin-Eijiff, F. Hubeek, S. van der Kroon, and J. Vader. 2008. All mixed up? Instrumental and emancipatory learning toward a more sustainable world: considerations for environmental education policymakers. Applied Environmental Education and Communication 7:55-65.

Wells, N. M., and G. Evans. 2003. Nearby nature: a buffer of life stress among rural children. Environment and Behavior 35(3):311-330.

Wells, N. M., and K. S. Lekies. 2006. Nature and the life course: pathways from childhood nature experiences to adult environmentalism. Children, Youth and Environments 16(1):1-24.

Wenger, E. 1998. Communities of practice: learning, meaning and identity. Cambridge University Press, Cambridge, UK.

Wilson, K. K., and G. E. B. Morren. 1990. Systems approaches for improvement in agriculture and resource management. MacMillan, New York, New York, USA. 